\title{
NETWORK COMPETENCE AND FIRM PERFORMANCE: THE MEDIATING ROLE OF ENTREPRENEURIAL INNOVATIVENESS AMONG MALAYSIAN CHINESE ENTREPRENEURS OF WHOLESALE BUSINESSES
}

\author{
Sulaiman Sajilan ${ }^{1 *}$ and Shehnaz Tehseen ${ }^{2}$ \\ ${ }^{1}$ Universiti Kuala Lumpur Business School, Level 8, Bangunan Yayasan Selangor, \\ No. 74, Jalan Raja Muda Abdul Aziz, 50300 Kuala Lumpur, Malaysia \\ ${ }^{2}$ Department of Management, Sunway University Business School, Sunway University, \\ 47500 Bandar Sunway, Selangor, Malaysia \\ *Corresponding author: drsulaiman@unikl.edu.my
}

Published online: 20 March 2019

To cite this article: Sajilan, S., and Tehseen, S. (2019). Network competence and firm performance: The mediating role of entrepreneurial innovativeness among Malaysian Chinese entrepreneurs of wholesale businesses. Asian Academy of Management Journal, 24(Supp. 1), 187-201. https://doi.org/10.21315/aamj2019.24.s1.13

To link to this article: https://doi.org/10.21315/aamj2019.24.s1.13

\begin{abstract}
Entrepreneurial innovativeness has been considered as one of the crucial factors for any firm to achieve its superior performances. The aim of this paper is to analyse the mediating effect of entrepreneurial innovativeness in the relationship between network competence and firm performances including financial performance, non-financial performance, and business growth. Data were collected from 150 Malaysian Chinese wholesalers from the states of Selangor and Kuala Lumpur. Non-probability sampling technique was used to get the target respondents. PLS-SEM technique was used to analyse the data. The results revealed positive as well as significant mediating influence of entrepreneurial innovativeness in the relationship between network competence and firm performances. This study also provides future recommendations and managerial implications.
\end{abstract}

Keywords: network competence, entrepreneurial innovativeness, financial performance, non-financial performance, business growth

(C) Asian Academy of Management and Penerbit Universiti Sains Malaysia, 2019. This work is licensed under the terms of the Creative Commons Attribution (CC BY) (http://creativecommons. org/licenses/by/4.0/). 


\section{INTRODUCTION}

Entrepreneurs and innovations have enormous contributions towards national wealth (Miller, 2015). Moreover, entrepreneurial capabilities including network competence and innovativeness are claimed to have positive impact on small and medium enterprises' (SMEs) performances during economic crises. Therefore, Farooq and Abideen (2015) have suggested for Malaysian SMEs to focus on the development of their entrepreneurial capabilities and innovations to better face economic crises. The networking capabilities or competence cannot be separated from innovation. Both are essential simultaneously. In Malaysia, it is generally perceived that Chinese community controls and manages most of Malaysian SMEs (Kheng \& Minai, 2016). According to Jamil, Omar, and Panatik (2014), Malaysian Chinese entrepreneurs owned $82 \%$ of wholesale businesses in Malaysia. This shows that Malaysian Chinese entrepreneurs own wholesale businesses more as compared to Malay and Malaysian Indian entrepreneurs. Most of businesses in Malaysia constitute small- and medium-sized enterprises.

According to Halim et al. (2015), the government of Malaysia has acknowledged SMEs as a key sector that catalyses the investment in this country. Moreover, Malaysian SME sector is viewed as a mean to transform country into a developed nation by 2020 (Halim et al., 2015). The Malaysian SMEs are more accountable to achieve superior performance (Lee \& Wong, 2015). Malaysian SMEs play a major role in the development of country's economy because they are the important service providers and traders to primary industries (Lee \& Wong, 2015). The contribution of Malaysian SMEs is well recognised in promoting the endogenous growth's sources and strengthening infrastructure for its economic development due to their size, sheer number, and nature of operations (Smolarski \& Kut, 2011). For instance, SMEs provide employment opportunities, support large firms, initiate improvements, foster growth and income, and are the main driver of economic transformation process of Malaysia (Hooi \& Ngui, 2014). SMEs create new jobs in most of the countries and contribute a lot in development of new products and other types of innovations (Lee \& Wong, 2015). SMEs existence is important for an efficient and a competitive market as well as for poverty reduction. That is the main reason for policy makers and governments to emphasise more on SMEs' development (Lee \& Wong, 2015). According to Lee and Wong (2015), Malaysian SMEs constitute $98.5 \%$ of total business establishments and contribute $33.15 \%$ and $57.5 \%$ towards GDP and employment, respectively. Due to vital contribution of SMEs, it is important to sustain their number to ensure their continuous contribution towards country's GDP, employment, and economic development (Lee \& Wong, 2015). Through managing ordinary resources in more effective and efficient way, SMEs can further enhance their performances and can survive for long-term in this competitive era. 
The network competence is perceived as one of the main characteristics of Chinese entrepreneurs in Malaysia (Kheng \& Minai, 2016). For instance, few studies have considered Chinese networks as basis of their SMEs' business success (Kheng \& Minai, 2016). However, there is insufficient empirical data to support this perception that strong networking is the key to success for Malaysian Chinese SMEs and is crucial to fill this theoretical and empirical gap in the literature (Kheng \& Minai, 2016). Moreover, it has been argued that the lack of information is one of the main obstacles that hinders the survival of Malaysian SMEs that may be because of poor networking of Malaysian entrepreneurs (Kheng \& Minai, 2016). A little number of studies has raised this issue under the context of Malaysian SMEs. Furthermore, this study argues that innovation plays a vital role in today's intense competitive business environment, thus, it can mediate the impact of network competence and firm performance relationship. The main purpose of this study is to investigate the mediating impact of innovation in the relationship between network competence and firm performances including perceived financial performance, non-financial performance, and business growth among Malaysian Chinese entrepreneurs that are operating their businesses in the wholesale industry. More specifically, this study seeks to answer the question: How does innovation mediate the impact of network competence on perceived firm financial performance, non-financial performance, and business growth?

\section{LITERATURE REVIEW}

\section{Importance of Network Competence and Innovation for Malaysian SMEs}

Kheng and Minai (2016) highlighted that $80.4 \%$ SMEs belong to the category of micro enterprises, and $17.6 \%$ and $2.1 \%$ are categorised as SMEs, respectively. Furthermore, service sector significantly contributes towards employment opportunities and total value added which are $71.4 \%$ and $66.8 \%$, respectively, which are higher as compared to other sectors. According to Halim, Ahmad, Ramayah, and Hanifah (2014), the contribution of Malaysian SMEs is relatively low as compared to SMEs of other developed countries due to their business context. For instance, there is intensive competition among SMEs in their respective industries which forces firms to differentiate their products or services from their competitors (Halim et al., 2014). Thus, the firms can better compete because of their important internal resources (e.g., competencies of entrepreneurs and innovative practices). The intensive competition requires entrepreneurs to equip themselves with necessary competencies (Ahmad, 2007) and to implement innovative practices in their firms (Halim et al., 2014). Innovation is essential because firms' survival and growth depend on offering attractive products and 
services (Halim et al., 2014). Therefore, the government is putting extra efforts to nurture the innovativeness among Malaysian SMEs in order to move the country into the innovation-led economy (Halim et al., 2014). Thus, Malaysian entrepreneurs are required to possess with the right type of skills, knowledge, and abilities needed for their businesses and to execute most suitable type of innovative practices within firm. It is imperative for Malaysia to be innovative because its economic and social development is contingent upon industrial growth (Zeng, Xie, $\&$ Tam, 2010). Moreover, businesses are moving away from the approaches of cost reduction techniques and are directing towards innovation to attain long-term success (Halim et al., 2014).

SMEs are confronted with various challenges such as limited resources and lack of or insufficient critical resources that impact on their performances (Korsakiene $\&$ Diskiene, 2015). Moreover, the role of owners/managers and their behaviours have been considered utmost important for the survival and success of SMEs (Korsakiene \& Diskiene, 2015). Scholars are agreed that success of SMEs is contingent upon various internal and external factors and that the failure rate of SMEs is higher relative to large firms (Korsakiene \& Diskiene, 2015). The higher failure rate among SMEs is due to their insufficient critical resources to recognise new business opportunities and to achieve desired business growth in market. Moreover, Tipu (2016) suggested to study behaviours of entrepreneurs that belong to small, medium, and large enterprises. The Malaysian SMEs' contribution was relatively unchanged at $29 \%$ for the year 2000 to 2004 and grew from $29.4 \%$ in 2005 to $31.4 \%$ in 2008 (Kheng \& Minai, 2016). However, Malaysian SMEs' contribution towards country's GDP is still lower than other developed countries. In Malaysia, it is generally perceived that Chinese community controls and manages most of Malaysian SMEs (Kheng \& Minai, 2016).

Malaysian SMEs are not achieving superior performances due to various challenges related to innovation, human capital development, and external business environment (Hooi \& Ngui, 2014). Malaysia is an emerging country in which the SMEs are facing tremendous pressure and multidimensional challenges in the recent competition of the 21 st century (Halim et al., 2015). Particularly, Malaysia is revealing slow performance along with the recent financial crisis due to slow improvement in their productivity of labour and is also becoming less attractive for investors (Halim et al., 2015). Furthermore in 2010, the Global Competitiveness Index rank of Malaysia has dropped from 21st to 24th (Halim et al., 2015). Moreover, the Malaysian SME sector is facing very high competition which compels the businesses to differentiate their services and products relative to their competitors and become more innovative (Halim et al., 2015). However, Malaysian SME sector is lacking the abilities to produce and differentiate services 
and products to compete with other developed countries. In order to move Malaysia towards innovation-led economy, Malaysian government has strived to nurture the innovativeness among its SMEs (Halim et al., 2015). Therefore, it is suggested that Malaysian entrepreneurs need to equip themselves with essential competencies and improve their innovative practices to compete globally (Halim et al., 2015).

\section{UNDERPINNING THEORY AND DEVELOPMENT OF THEORETICAL FRAMEWORK}

Resources-based view (RBV) theory is the underpinning theory in this study. The RBV was initially introduced by Penrose (1959) which was further developed by many other researchers such as Wernerfelt (1984), Barney (1991), Grant (1991), and Peteraf (1993). According to Hassan, Yaacob, and Abdullatif (2014), RBV claims that firms' internal resources can be viewed as strength for firms to response for challenges and to the avail opportunities from business environment as well as to "neutralise" the external threats such as intense competition. The internal firms' resources are their strengths that can be used to overcome internal weaknesses such as poor decision-making processes and poor management of resources within the organisation. The internal resources owned by firms enable them to maintain and sustain competitive advantage, profitability, and business growth (Wernerfelt, 1984). The skills of firms' management, organisational routines and processes, and knowledge and information controls are the important internal resources that are critical to sustain firm competitive advantage (Barney, 1991). Using RBV, the network competence and innovativeness can be considered as internal resources for any firm that lead towards their competitive advantages and business success. The theoretical framework has been developed by taking network competence (NC) as an independent variable; entrepreneurial innovativeness (EI) as a mediator; and perceived firm financial performance (FP), non-financial performance (NFP), and business growth $(\mathrm{BG})$ as three dependent variables. Figure 1 shows the theoretical framework for this study. 
Dependent variables

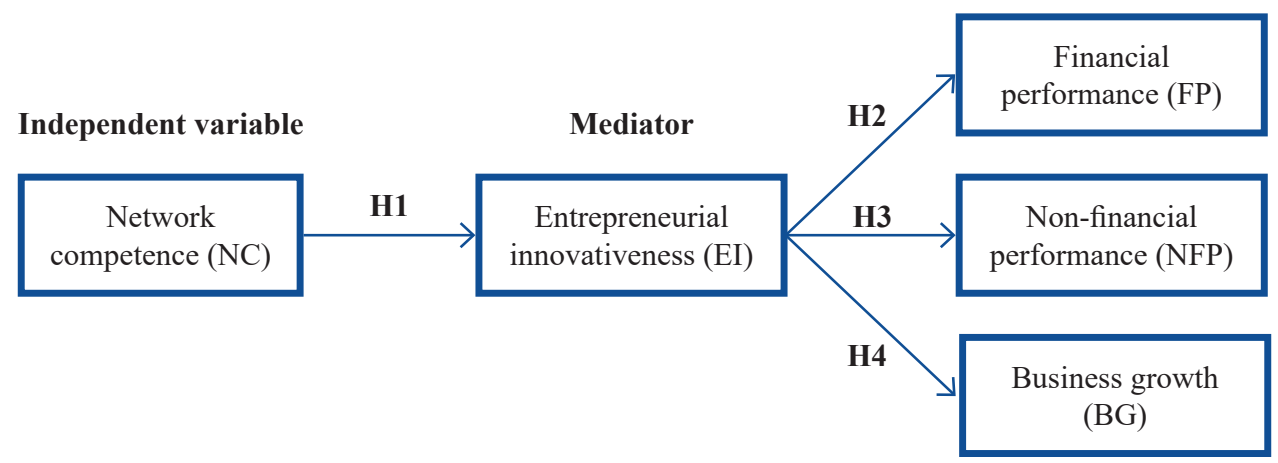

Figure 1. Proposed theoretical framework

\section{Development of Hypotheses}

Four hypotheses have been developed based on the proposed theoretical framework as follows:

\section{Impact of network competence on entrepreneurial innovativeness}

The network competence is the ability of entrepreneurs to develop and maintain long-term relationships with customers, suppliers, and other interested stakeholders. Network competence represents the ability of the firms to develop as well as manage relations with their customers, suppliers, and other firms, and to effectively deal the interactions with these external parties (Ritter, Wilkinson, \& Johnston, 2002; Ritter, 1999). Thus, it is the ability to create, use, and develop networks through social interactions with external parties (Brinckmann, 2008). Whereas, entrepreneurial innovativeness refers to the ability of entrepreneurs to support and engage in developing new ideas and translating them into important business opportunities (Halim et al., 2014). Chin, Hamid, Rasli, and Tat (2014) have emphasised on developing and maintaining long-term relationships with external parties such as suppliers, competitors, and customers by Malaysian SMEs to get critical resources for their survival, growth, and success.

The literature has widely acknowledged the importance of external factors for innovative practices of SMEs (Saunila \& Ukko, 2014). The SMEs in service industry are more knowledge-intensive that impact on their innovative practices. In other words, SMEs in service industry such as retail and wholesale SMEs need new knowledge and information to produce innovations. Innovation not only comes from employee's ideas, but the external knowledge/information is also 
vital source of innovations (Saunila \& Ukko, 2014). Moreover, Saunila and Ukko (2014) found the importance of both internal and external factors in enhancing the innovation capability of SMEs. The importance of network competence can be viewed through absorptive capacity aspect that was originally constructed by Cohen and Levinthal (1990). Moreover, Swink (2006) also recognised the firm's ability of networking or its external collaboration as a key to its innovative success. The inter-firm relationships influence the degree of tacit knowledge transfer from partners that also affect the capability of firms' innovation (Cavusgil, Calantone, \& Zhao, 2003). Therefore, the interactions with external parties such as customers, competitors, suppliers, industry associations, and others can provide useful external inputs to enhance the innovative capability of firms (Lawson \& Samson, 2001; Romijn \& Albaladejo, 2002). Thus, based on above discussion, the following hypothesis is developed:

H1: There is a positive relationship between network competence and entrepreneurial innovativeness.

\section{Mediating role of entrepreneurial innovativeness}

Survival is the key to success. For instance, Headd (2003) has viewed success as survival through profitability, sales growth, and improved market share. According to $\mathrm{Ng}$ and Hamilton (2015), the previous researchers have linked five types of capabilities with the performance of firms: human, innovation, marketing, financial, and organisational. There is a wide evidence regarding the positive impact of innovation capability on firms' performance ( $\mathrm{Ng} \&$ Hamilton, 2015). Although SMEs engage into less innovative practices as compared to large firms because of their scarce resources, however, they are considered as the most accurate platform for innovations due to their very close association with employees, suppliers, and customers (Yasin, Nawab, Bhatti, \& Nazir, 2014). Many scholars have emphasised on innovative practices and innovation-led strategies for SMEs for their survival, growth, and long-term success in the market ( $\mathrm{Ng} \&$ Hamilton, 2015). A number of studies have widely recognised the importance of innovation in achieving success, growth, and competitive advantage for SMEs, both in developed and developing countries (Yasin et al., 2014). Many studies have found innovation as a key factor for SMEs' success (Olughor, 2015; Salim \& Sulaiman, 2011). Innovation leads to competitive advantage of SMEs. For example, Gunday, Ulusoy, Kilic, and Alpkan (2011) stated that SMEs execute innovative strategies/practices to achieve superior performance and competitive advantage. Similarly, various studies have provided empirical evidence regarding the direct positive impact of innovation on Malaysian SMEs (Hilmi, Ramayah, Mustapha, \& Pawanchik, 2010). Furthermore, several studies have provided the empirical evidence regarding the mediating role 
of innovation under various contexts (Salisu \& Bakar, 2018; Rodríguez \& Nieto, 2016). Thus, based on above literature, it can be hypothesised that:

$\mathrm{H} 2$ : Entrepreneurial innovativeness mediates the positive relationship between network competence and firm financial performance.

H3: Entrepreneurial innovativeness mediates the positive relationship between network competence and firm non-financial performance.

H4: Entrepreneurial innovativeness mediates the positive relationship between network competence and firm business growth.

\section{METHODOLOGY}

\section{Sample, Data Collection, and Data Analysis}

The Malaysian wholesale SMEs were the population of this study. The present study constitutes the sample of 150 respondents who were the entrepreneurs of SMEs in the wholesale SMEs from the two most urbanised states of West Malaysia namely Selangor and Kuala Lumpur. Snowball sampling method was used to collect the data from target respondents. Sample size was assessed by using $\mathrm{G}^{*}$ Power 3.1.9.2 software which is an extension of the previous versions (Faul, Erdfelder, Lang, \& Buchner, 2007). Since, our PLS model involves one predictor, therefore, a minimum sample size of 55 was needed to create a power of 0.80 for our PLS model with 0.15 of medium effect size (Hair, Sarstedt, Ringle, \& Gudergan, 2018; Hair, Hult, Ringle, \& Sarstedt, 2014, 2017). Thus, using 150 respondents, our PLS model has exceeded the minimum sample size requirement criterion and could generate the power of more than 0.90 with medium effect size $\left(f^{2}\right)$ of 0.15 . The data were collected from target wholesale SMEs' entrepreneurs through the standard and well-established questionnaire that was adopted or adapted from existing studies.

\section{Data Analysis and Results}

The respondents consisted of $36.7 \%$ males and $63.3 \%$ females. Most of the respondents belong to the age group between $41-50$ years $(56.0 \%)$. The majority of respondents were married (58.0\%). Most of the respondents were having a bachelor's degree education (56.7\%); and $72.0 \%$ belong to upper middle-class families. Data were then analysed through structural equation modelling partial least square (SEM-PLS) technique by using Smart PLS 3.2.7 software. The twostage approach was used as suggested by Hair et al. (2018) that included the 
examination of the measurement model (reliability and validity assessment) and structural model analysis (hypothesis testing).

\section{Measurement model analysis}

The reliability and validity of the measures were assessed to evaluate the measurement model (Hair et al., 2018). For reliability, item's loadings and composite reliability were analysed that should be more than 0.7 . The average variance extracted (AVE) was examined to assess the convergent validity $(\mathrm{AVE}>0.5)$ and finally the heterotrait-monotrait $(\mathrm{HTMT})$ ratio of correlations was used for discriminant validity (HTMT < 0.90) (Henseler, Ringle, \& Sinkovics, 2009; Henseler, Ringle, \& Sarstedt, 2015) as shown in Table 1. The measurement model analysis including composite reliability (CR), AVE, and factors' loadings is shown in Table 2.

Table 1

HTMT criterion

\begin{tabular}{lccccc}
\hline & BG & EI & FP & NC & NFP \\
\hline BG & & & & & \\
EI & 0.826 & & & & \\
& $(0.707,0.943)$ & & & & \\
FP & 0.356 & 0.451 & & & \\
& $(0.200,0.502)$ & $(0.299,0.613)$ & & & \\
NC & 0.357 & 0.332 & 0.555 & & \\
& $(0.221,0.524)$ & $(0.204,0.466)$ & $(0.375,0.716)$ & & \\
NFP & 0.708 & 0.638 & 0.587 & 0.443 & \\
& $(0.556,0.860)$ & $(0.495,0.766)$ & $(0.423,0.735)$ & $(0.263,0.588)$ & \\
\hline
\end{tabular}

Note: HTMT $<0.90$

Table 2

Results of measurement model

\begin{tabular}{lcccr}
\hline Constructs & Items & Loadings & CR & AVE \\
\hline Network competence (NC) & NC1 & 0.846 & 0.855 & 0.598 \\
& NC2 & 0.697 & & \\
NC3 & 0.821 & & \\
Entrepreneurial innovativeness (EI) & NC4 & 0.719 & & \\
& EI1 & 0.808 & 0.823 & 0.546 \\
& EI2 & 0.796 & & \\
& EI3 & 0.815 & & \\
& EI4 & 0.483 & & \\
\hline
\end{tabular}

(continued on next page) 
Table 2 (continued)

\begin{tabular}{lcccr}
\hline Constructs & Items & Loadings & CR & AVE \\
\hline Financial performance (FP) & FP1 & 0.766 & 0.878 & 0.642 \\
& FP2 & 0.844 & & \\
& FP3 & 0.819 & & \\
Non-financial performance (NFP) & FP4 & 0.774 & & \\
& NFP1 & 0.883 & 0.897 & 0.745 \\
& NFP2 & 0.914 & & \\
Business growth (BG) & NFP3 & 0.788 & & \\
& BG1 & 0.754 & 0.806 & 0.581 \\
& BG2 & 0.737 & & \\
\hline
\end{tabular}

Thus, the above tables show adequate results for the measurement model because of the sufficient reliability, convergent, and discriminant validity values. The structural model analysis and hypotheses testing are presented in the following section.

\section{Assessment of the structural model}

The hypothesis testing was done by using the assessment of structural model. Collinearity was examined before testing the hypotheses. The variance inflation factor (VIF) was assessed to analyse the issue of collinearity that was found less than the threshold of 3, as recommended by Hair et al. (2018). After examining the VIF values, the bootstrapping procedure with 5,000 resamples was used to identify the standard path coefficients and $t$-values (Hair et al., 2018).

\section{Testing of hypotheses}

Table 3 reveals the results of hypotheses testing. The positive and significant influence of network competence was found on entrepreneurial innovativeness. Similarly, innovativeness was also found as a mediator between network competence and financial performance, also between network competence and non-financial performance, as well as between network competence and business growth. Therefore, $\mathrm{H} 1(\beta=0.298, t=3.987), \mathrm{H} 2(\beta=0.112, t=2.965)$, $\mathrm{H} 3(\beta=0.161, t=3.334)$, and $\mathrm{H} 4(\beta=0.195, t=3.364)$ are supported. 
Table 3

Hypotheses testing through structural model

\begin{tabular}{lccc}
\hline Hypotheses & Std. Beta & Std. Error & $t$-values \\
\hline $\mathrm{H} 1: \mathrm{NC} \rightarrow$ EI & 0.298 & 0.075 & $3.987^{* * *}$ \\
$\mathrm{H} 2: \mathrm{NC} \rightarrow$ EI $\rightarrow$ FP & 0.112 & 0.038 & $2.965^{* * *}$ \\
$\mathrm{H} 3: \mathrm{NC} \rightarrow \mathrm{EI} \rightarrow$ NFP & 0.161 & 0.048 & $3.334^{* * *}$ \\
$\mathrm{H} 4: \mathrm{NC} \rightarrow \mathrm{EI} \rightarrow$ BG & 0.195 & 0.054 & $3.364^{* * *}$ \\
\hline
\end{tabular}

Note: Critical $t$-value $2.57^{* * *}($ significance level $=1 \%$ )

The values of coefficients of determination $\left(R^{2}\right)$ were 0.089 for entrepreneurial innovativeness (EI), 0.140 for financial performance (FP), 0.293 for non-financial performance (NFP), and 0.428 for business growth (BG). However, according to Cohen's (1988) guide for examining the value of $R^{2}$, the $R^{2}$ values were found as moderate because they were more than 0.13 . On the other hand, the $\mathrm{Q}^{2}$ values of all the dependent variables were above 0 that indicate the adequate predictive relevance.

\section{DISCUSSION AND CONCLUSION}

This study aims to assess the mediating influence of entrepreneurial innovativeness in the relationship between network competence and firm performances. The findings revealed the positive and significant mediating impact of entrepreneurial innovativeness in the relationship between network competence and firm performances. Thus, the results clearly indicate that network competence alone is not sufficient for Malaysian Chinese wholesale firms to achieve business success. In fact, their innovativeness play an important role as well. This is because the customers' needs and demands are unpredictable, and Malaysian customers are most likely to buy innovative products. Thus, innovation is crucial for Malaysian wholesale businesses. The findings of this study provide useful insights and implications for the Malaysian wholesalers to implement innovative practices in their wholesale businesses for achieving superior firm performances. This is because to attract and retain customers for the long-term, it is essential for businesses to produce products with innovative features. The innovative features could provide competitive edge to the Malaysian wholesalers to retain their target customers for the long run.

There are a few limitations of this study. First, it has used a cross-sectional design which prevented the investigation of cause-and-effect relationship between the constructs. While applying SEM in cross-sectional studies, the cause-and- 
effect relationship cannot be measured, only association among constructs could be measured (Hooi \& Ngui, 2014). Therefore, to determine the causality in a relationship, a longitudinal study is needed with similar intent. Second, this study investigated the impact of capabilities on firm performances only among Chinese entrepreneurs. Since Malaysia is a multicultural society, future studies should conduct the research across other ethnic groups including Malay and Indian entrepreneurs. Finally, the data was collected from the same type of respondents, i.e., the entrepreneurs; therefore, common method bias could be an issue in this study. Future studies should use statistical as well as procedural remedies to control the impact of common method biases.

This study has provided the important empirical evidence regarding the mediating role of innovations for Malaysian Chinese businesses. This means that innovations, particularly the incremental innovations, act as a source of mechanism in the relationship between network competence and firm performances of Chinese wholesale firms. Thus, this reveals the significant contribution of innovations for the success of Chinese wholesale businesses.

\section{ACKNOWLEDGEMENTS}

The authors would like to thank Universiti Kuala Lumpur for providing the research grant under Short-Term Research Grant (STRG) scheme (UniKL No. str15063).

\section{REFERENCES}

Ahmad, N.H. (2007). A cross cultural study of entrepreneurial competencies and entrepreneurial success in SMEs in Australia and Malaysia. PhD dissertation, University of Adelaide, South Australia.

Barney, J. (1991). Firm resources and sustained competitive advantage. Journal of Management, 17(1), 99-120. https://doi.org/10.1177/014920639101700108

Brinckmann, J. (2008). Competence of top management teams and success of new technology-based firms: A theoretical and empirical analysis concerning competencies of entrepreneurial teams and the development of their ventures. Wiesbaden: Gabler Publishing.

Cavusgil, S., Calantone, R.J., \& Zhao, Y. (2003). Tacit knowledge transfer and firm innovation capability. Journal of Business \& Industrial Marketing, 18(1), 6-21. https://doi.org/10.1108/08858620310458615

Chin, T.A., Hamid, A.B.A., Rasli, A., \& Tat, H.H. (2014). A literature analysis on the relationship between external integration, environmental uncertainty and firm performance in Malaysian SMEs. Procedia-Social and Behavioral Sciences, 130(May), 75-84. https://doi.org/10.1016/j.sbspro.2014.04.010 
Cohen, J. (1988). Statistical power analysis for the behavioural sciences. Hillside, NJ: Lawrence Earlbaum Associates. https://doi.org/10.1002/bs.3830330104

Cohen, W.M., \& Levinthal, D.A. (1990). Absorptive capacity: A new perspective on learning and innovation. Administrative Science Quarterly, 35(1), 128-152. https://doi.org/10.2307/2393553

Farooq, W., \& Abideen, Z.U. (2015). SMEs' preparedness to face economic crisis: A proposed framework for Malaysian SMEs. East West Journal of Business and Social Studies, 4(2), 66-79.

Faul, F., Erdfelder, E., Lang, A.G., \& Buchner, A. (2007). G* Power 3: A flexible statistical power analysis program for the social, behavioral and biomedical sciences. Behavior Research Methods, 39(2), 175-191. https://doi.org/10.3758/ BF03193146

Grant, R. (1991). The resource-based theory of competitive advantage: Implications for strategy formulation. California Management Review, 33(2), 114-135. https:// doi.org/10.2307/41166664

Gunday, G., Ulusoy, G., Kilic, K., \& Alpkan, L. (2011). Effects of innovation types on firm performance. International Journal of Production Economics, 133(2), 662-676. https://doi.org/10.1016/j.ijpe.2011.05.014

Hair, J.F., Hult, G.T.M., Ringle, C.M., \& Sarstedt, M. (2014). A primer on partial least squares structural equation modeling (PLS-SEM). Thousand Oaks, CA: Sage.

Hair, J.F., Hult, G.T.M., Ringle, C.M., \& Sarstedt, M. (2017). A primer on partial least squares structural equation modeling (PLS-SEM) (2nd ed.). Thousand Oaks, CA: Sage.

Hair, J.F., Sarstedt, M., Ringle, C.M., \& Gudergan, S.P., (2018). Advanced issues in partial least squares structural equation modeling (3rd ed.). Thousand Oaks, CA: Sage.

Halim, H.A., Ahmad, N.H., Ramayah, T., \& Hanifah, H. (2014). The growth of innovative performance among SMEs: Leveraging on organisational culture and innovative human capital. Journal of Small Business and Entrepreneurship Development, 2(1), 107-125.

Halim, H.A., Ahmad, N.H., Ramayah, T., Hanifah, H., Taghizadeh, S.K., \& Mohamad, M.N. (2015). Towards an innovation culture: Enhancing innovative performance of Malaysian SMEs. Academic Journal of Interdisciplinary Studies, 4(2), 85-94. https://doi.org/10.5901/ajis.2015.v4n2p85

Hassan, T.M.R.T., Yaacob, M.R., \& Abdullatiff, N.K. (2014). Sustaining SMEs woodbased product manufacturing through best practices: The case of indigenous entrepreneurs in Kelantan. Procedia-Social and Behavioral Sciences, 115(February), 221-234. https://doi.org/10.1016/j.sbspro.2014.02.430

Headd, B. (2003). Redefining business success: Distinguishing between closure and failure. Small Business Economics, 21(1), 51-61. https://doi. org/10.1023/A:1024433630958

Henseler, J., Ringle, C.M. \& Sarstedt, M. (2015). A new criterion for assessing discriminant validity in variance based structural equation modelling. Journal of the Academy of Marketing Science, 43(1), 115-135. https://doi.org/10.1007/ s1 1747-014-0403-8 
Henseler, J., Ringle, C.M. \& Sinkovics, R.R. (2009). The use of partial least squares path modelling in international marketing. Advances in International Marketing, 20(1), 277-319.

Hilmi, M.F., Ramayah, T., Mustapha, Y., \& Pawanchik, S. (2010). Product and process innovativeness: Evidence from Malaysian SMEs. European Journal of Social Sciences, 16(4), 556-565.

Hooi, L.W., \& Ngui, K.S. (2014). Enhancing organizational performance of Malaysian SMEs. International Journal of Manpower, 35(7), 973-995. https://doi. org/10.1108/IJM-04-2012-0059

Jamil, A., Omar, R., \& Panatik, S.A. (2014). Entrepreneurial passion, achievement motivation goals and behavioural engagements in Malaysia: Are there any differences across ethnic groups? Asian Social Science, 10(17), 17-28. https://doi.org/10.5539/ass.v10n17p17

Kheng, L.K., \& Minai, M.S. (2016). The network characteristic of Chinese SMEs in Malaysia and their performance. In N. Mohd Sidek, S. Ali, \& M. Ismail (Eds.), Proceedings of the ASEAN Entrepreneurship Conference 2014 (pp. 39-47). Singapore: Springer. https://doi.org/10.1007/978-981-10-0036-2_4

Korsakiene, R. \& Diskiene, D. (2015). Do competencies of entrepreneurs and managers influence internationalization processes? Investigation of Lithuanian SMEs. In Proceedings of the 10th European Conference on Innovation and Entrepreneurship ECIE 2015, The University of Genoa, Italy, 17-18 September 2015.

Lawson, B., \& Samson, D. (2001). Developing innovation capability in organisations: A dynamic capabilities approach. International Journal of Innovation Management, 5(3), 377-400. https://doi.org/10.1142/S1363919601000427

Lee, C.S., \& Wong, K.Y. (2015). Knowledge management performance measurement in micro-, small- and medium-sized enterprises: An exploratory study. Business Information Review, 32(4), 204-211. https://doi.org/10.1177/0266382115615262

Miller, D. (2015). A downside to the entrepreneurial personality? Entrepreneurship Theory and Practice, 39(1), 1-8. https://doi.org/10.1111/etap.12130

Ng, P.Y., \& Hamilton, R.T. (2015). Capabilities, strategy, and performance: The case of ICT firms in New Zealand. Journal of Asia-Pacific Business, 16(4), 302-327. https://doi.org/10.1080/10599231.2015.1091710

Olughor, R.J. (2015). Effect of innovation on the performance of SMEs organizations in Nigeria. Management, 5(3), 90-95.

Penrose, E. (1959). The theory of the growth of the firm. Oxford: Blackwell.

Peteraf, M.A. (1993). The cornerstones of competitive advantage: A resource-based view. Strategic Management Journal, 14(3), 179-191. https://doi.org/10.1002/smj. 4250140303

Ritter, T. (1999). The networking company: Antecedents for coping with relationships and networks effectively. Industrial Marketing Management, 28(5), 467-479. https://doi.org/10.1016/S0019-8501(99)00075-9

Ritter, T., Wilkinson, I.F., \& Johnston, W.J. (2002). Measuring network competence: Some international evidence. Journal of Business \& Industrial Marketing, 17(2/3), 119138. https://doi.org/10.1108/08858620210419763 
Rodríguez, A., \& Nieto, M.J. (2016). Does R\&D offshoring lead to SME growth? Different governance modes and the mediating role of innovation. Strategic Management Journal, 37(8), 1734-1753. https://doi.org/10.1002/smj.2413

Romijn, H., \& Albaladejo, M. (2002). Determinants of innovation capability in small electronics and software firms in southeast England. Research Policy, 31(7), 1053-1067. https://doi.org/10.1016/S0048-7333(01)00176-7

Salim, I.M., \& Sulaiman, M. (2011). Organizational learning, innovation and performance: A study of Malaysian small and medium sized enterprises. International Journal of Business and Management, 6(12), 118-125. https://doi.org/10.5539/ijbm. v6n12p118

Salisu, Y., \& Bakar, L.J.A. (2018). Strategic alliance and the performance of SMEs in developing economies: The mediating role of innovation strategy. Asian Journal of Multidisciplinary Studies, 6(2), 47-56.

Saunila, M., \& Ukko, J. (2014). Intangible aspects of innovation capability in SMEs: Impacts of size and industry. Journal of Engineering and Technology Management, 33, 32-46. https://doi.org/10.1016/j.jengtecman.2014.02.002

Smolarski, J., \& Kut, C. (2011). The impact of venture capital financing method on SME performance and internationalization. International Entrepreneurship and Management Journal, 7(1), 39-55. https://doi.org/10.1007/s11365-009-0128-1

Swink, M. (2006). Building collaborative innovation capability. Research-Technology Management, 49(2), 37-47. https://doi.org/10.1080/08956308.2006.11657367

Tipu, S.A.A. (2016). Comparing the behaviour of opportunity and necessity driven entrepreneurs. International Journal of Entrepreneurship and Small Business, 27(1), 84-107. https://doi.org/10.1504/IJESB.2016.073359

Wernerfelt, B. (1984). A resource-based view of the firm. Strategic Management Journal, 5(2), 171-180. https://doi.org/10.1002/smj.4250050207

Yasin, G., Nawab, S., Bhatti, K.K., \& Nazir, T. (2014). Relationship of intellectual stimulation, innovations and SMEs performance: Transformational leadership a source of competitive advantage in SMEs. Middle-East Journal of Scientific Research, 19(1), 74-81.

Zeng, S.X., Xie, X.M., \& Tam, C.M. (2010). Relationship between cooperation networks and innovation performance of SMEs. Technovation, 30(3), 181-194. https://doi. org/10.1016/j.technovation.2009.08.003 